\title{
Higher Education Access and Success through Distance English Language Learning
}

\author{
By Maureen Snow Andrade*
}

\begin{abstract}
Increased access to post-secondary education is necessary to advance the global knowledge society. Recognition of the benefits of higher education for individuals and their communities and nations has resulted in a large demand for higher education which institutions are finding difficult to fulfill due to adherence to traditional practices, policies, organizational structures, and delivery methods. Barriers for potential learners include access in terms of cost, admission standards, and scheduling. Governments around the world are determining strategies to overcome these barriers and provide opportunities for traditionally underserved populations. Distance education allows for the expansion of higher education courses and degrees in ways that are flexible and affordable for a range of diverse and nontraditional learners. As English is the medium of instruction for much educational content, particularly online instruction designed for a global audience, academic English language proficiency is a prerequisite for success. Innovative approaches are needed to help learners acquire English language skills in online environments and build a foundation to further educational opportunity. This paper describes innovative approaches that address issues of access and learner preparation in terms of academic English language and learning strategies that have been implemented by two institutions in the United States.
\end{abstract}

Global education is being shaped by a number of forces. One is the overall growth in higher education enrollments. From 2000 to 2009, enrollments of undergraduate students in the United States rose by 34\%-from 13.2 to 17.6 million students (Aud et al., 2011). These numbers are projected to grow even further as $66 \%$ of all jobs will require some form of post-secondary education by the year 2020 (Carnevale, Smith, \& Strohl, 2010). To support this need, federal and state governments and non-profit educational organizations (e.g., Lumina Foundation for Education; Commission on Access, Admissions and Success in Higher Education; the National Governor's Association) have set goals for college completion.

Similar trends and initiatives are evident worldwide. Indeed, a revolution in higher education, referred to as massification, is occurring to support increased social mobility through new types of funding, lower admissions

*Professor and Associate Vice President - Academic Programs, Utah Valley University, USA.

https://doi.org/10.30958/aje.1-3-2

doi=10.30958/aje.1-3-2 
criteria, and greater support for underserved populations (Altbach, Reisberg, \& Rumbley, 2010). The Europe 2020 strategy, designed to promote economic growth and sustainability, outlines five specific goals including employment ( $75 \%$ of individuals between the ages of 20 and 64 will be employed), and education (the percentage of early school leavers will be below 10\%, and $40 \%$ of 30-34 year-olds will have completed tertiary education) (European Commission, 2014). The other three goals-research and development, fighting poverty and social exclusion, and climate change and energy sustainability - are also impacted by education although some more directly than others. Poverty, for instance, is directly impacted as income rises with level of education. Research and development is dependent on educated individuals. A more informed and aware citizenry could certainly impact the outcomes of climate change and energy sustainability as well.

To address demand and meet completion goals, higher education institutions must be prepared to expand access to students from a wide range of backgrounds - to be inclusive - and provide related support to ensure student success. This includes those for whom English is not a first language. English continues to increase as the dominant language of scientific and technological communities (Altbach et al., 2009). Additionally, it is the language in which much tertiary level education, and particularly online programs, is delivered (Andrade, 2013).

This paper shares approaches for offering low cost, high quality distance English language coursework and degrees globally in order to expand access and support learner success. Courses are designed to include the necessary components for language acquisition including face-to-face weekly class meetings in students' local areas and native-English speaking peer tutors to build linguistic competency. Pedagogical models for the courses are designed to develop learner autonomy. Details about course features and outcomes are shared.

\section{Non-Native English Language Speakers}

Non-native English Language Speakers (NNESs) may be residents in an English-speaking country who arrived in their childhood or early youth, or part of the globally mobile student population, which increased by 50\% from 2004 to 2010 (Choudaha, Chang, \& Kono, 2013). The latter are seeking educational opportunity in English-medium higher education institutions, which is creating significant competition among countries such as the United States, United Kingdom, Canada, and Australia (Choudaha, Chang, \& Kono, 2013).

Although nations are striving to close the achievement gap in higher education attainment and expand access to those who have been historically underrepresented, the specific needs of NNESs in terms of academic English language proficiency may not be widely recognized as an at-risk factor. This is at least partially due to this population often not being identified or tracked at institutional or national levels, at least in the United States (Andrade, Evans, \& 
Hartshorn, in press-b). Other reasons for this situation include lack of understanding of English language acquisition processes, differences between academic and general English proficiency (Krashen, 1985), and the fact that in some institutions, NNESs may represent a small percentage of student enrollments and be almost invisible. In other cases, however, such as in Australia where $21.4 \%$ of the total higher education enrollment consists of international students (Choudaha et al, 2013), issues related to continued development of English skills must and are being taken very seriously so that graduates are prepared for possible residency and employment in Australia (Arkoudis, Baik, \& Richardson, 2012; Australian Universities Quality Agency, 2009; Birrell, 2006).

Results of a national survey indicate that institutions in the United States generally require a single standardized test of English language proficiency for admission and may exempt individuals from testing based on their country of origin or citizenship rather than any clear indication of their English language skills (Andrade, Evans, \& Harshorn, 2014). Similarly, few require further testing when students arrive on campus, even for diagnostic purposes. Thus, students are typically not required to take steps to develop their English language skills further; the outcomes of these practices may not only be additional challenges in terms of academic success but leaving graduates unprepared with the professional level English language skills needed for employment (Andrade, Evans, \& Hartshorn; in press-b). Because institutions do not track NNESs as a separate group, their levels of success are unknown.

Andrade et al. (in press) refer to this situation-liberal exemptions from admission testing and determining proficiency based on a single measure, limited post-admission diagnostic testing, lack of structures to require further English language development, and inconsistent or no tracking of success benchmarks for NNESs - as a web of disconnects that result in institutions not only not having any real knowledge of the level of success of these students, but in not preparing them adequately for their future professions in terms of English language proficiency.

To address English development needs, innovative approaches are needed. The institutional models next described focus on aspects of both access and success in relation to global educational opportunity. For a case study related to the two institutions, which provides a more detailed analysis, see Andrade (2014).

\section{Access}

"Distance education represents an area of enormous potential for higher education systems around the world struggling to meet the needs of growing and changing student populations" (Altbach et al., 2009, p. xvi). It increases access to higher education opportunity. The defining characteristic of distance learning to provide educational offerings anywhere and anytime opens the way 
for those who need a more flexible arrangement for their educational pursuits than is provided by traditional brick-and-mortar institutions. This may also be partly why distance learning is experiencing exponential growth. In 2012, $33.5 \%$ of all students in higher educational institutions in the United States were enrolled in a distance course compared to 9.6\% in 2002 (Allen \& Seaman, 2014).

Barriers to higher education access include academic preparation, English language preparation (in the case of English-medium programs), cost, familiarity with higher education culture and processes, and personal factors including time constraints and responsibilities related to employment and family. Governments from around the world have established new approaches to access, particularly for populations such as those disadvantaged by geography, culture, history, socioeconomic status, gender, ethnicity (or caste in the case of India), or first generational status (Altbach et al., 2009). Strategies to increase access include lowering admission standards and reserving space for certain populations. Governments are also addressing cost issues by providing grants, loans, and scholarships; however, "cost remains an enormous barrier to access" (Altbach et al., 2009, p. vi).

Table 1 indicates how two institutions in the United States are expanding global access through distance learning preparatory work in English language and other areas and lowering barriers in terms of academic preparation and cost. These approaches support the democratization of higher education so that associated outcomes such as higher wages, satisfying employment, health and well-being, confidence, critical thinking and reasoning abilities, parenting skills, and community contributions can be realized (Utah Women \& Education Initiative, 2014). Indeed, "being able to access knowledge from any location, at any time, for any age, and in many ways, has become a requirement for individual, community, and collective well-being" (Hanna, 2013, p. 684).

Institution 1 serves students primarily from Asia and the Pacific in its online programs whereas Institution 2 enrolls students mostly from Mexico, Central and South America, Africa, and some European countries. In both cases, adjustments have been made in admission standards and cost to expand access. Institution 1 is in the process of developing fully online degrees while Institution 2 has online certificate, associate, and bachelor degrees in place. The latter makes it possible for students in developing countries to earn a bachelor's degree for approximately $\$ 2,400$; in developed countries the cost is approximately $\$ 8,000$. The institutions currently have somewhat different purposes with Institution 1 focused on preparing students for on-campus study and Institution 2 preparing them to complete online degrees. Both have identified processes for developing and delivering low-cost and high quality online learning. 
Table 1. Features of Access

\begin{tabular}{|c|c|c|}
\hline & Institution 1 & Institution 2 \\
\hline $\begin{array}{c}\text { Admission } \\
\text { Requirements }\end{array}$ & $\begin{array}{l}\text { No English language } \\
\text { requirements; students take an } \\
\text { English language placement } \\
\text { test; no academic requirements } \\
\text { (e.g., high school completion); } \\
\text { students must apply to the } \\
\text { institution through the regular } \\
\text { admission process and meet } \\
\text { requirements to be admitted as } \\
\text { degree-seeking on-campus } \\
\text { students. }\end{array}$ & $\begin{array}{l}\text { Low-intermediate English } \\
\text { proficiency; students take an } \\
\text { English language placement test; } \\
\text { no academic requirements (e.g., } \\
\text { high school completion); } \\
\text { complete English, math, and } \\
\text { student development courses with } \\
\text { a B average to be admitted to } \\
\text { online degree programs. }\end{array}$ \\
\hline Cost & $\begin{array}{l}\text { Variable tuition scale reflective } \\
\text { of local economies; ranges from } \\
\$ 25-\$ 110 / \text { credits hour as } \\
\text { follows: } \$ 110 / \text { credit hour - } \\
\text { United States and Canada; } \\
\text { \$5/credit hour - Australia, } \\
\text { China, Hong Kong, Korea, New } \\
\text { Zealand, Taiwan; } \$ 25 / \text { per credit } \\
\text { hour - Fiji, French Polynesia, } \\
\text { Malaysia, Mongolia, Papua } \\
\text { New Guinea, Philippines, } \\
\text { Samoa, Tonga, Thailand. }\end{array}$ & $\begin{array}{c}\text { Variable tuition scale reflective of } \\
\text { local economies; ranges from } \\
\$ 20-\$ 65 / \text { credit hour as follows: } \\
\$ 20-\$ 45 \text { in developing countries } \\
\text { and } \$ 45-\$ 65 \text { in developed } \\
\text { nations. }\end{array}$ \\
\hline
\end{tabular}

\section{Success}

Success in the online English language courses consists of a number of elements. First and foremost is the acquisition of academic English language skills that will prepare students for further studies and degree completion. Secondly, students need to be self-directed or autonomous to some degree to succeed in an online course and possess study skills and strategies that support learning. Thus, at both institutions, courses are based on language acquisition and learning theory. While the course design models differ, the commonalities in approaches and content between the courses at the two institutions triangulate, in a sense, the efficacy of integrating language acquisition with the development of self-direction or autonomy to create an instructional model that positively impacts the achievement of desired learning outcomes.

\section{Four Strands}

Learning a foreign language through distance education requires interaction, specifically input and output. Language learners need opportunities to read and listen to the target language and produce language, negotiate meaning, test rules, and get feedback (Krashen, 1985; Long, 1996; Swain, 1995). They need to study the rules, systems, and structure of the language, and 
practice listening, reading, writing, and speaking using the language they have acquired in order to develop fluency. A well-balanced language course consists of four strands in equal proportion: meaning-focused input, meaning-focused output, deliberate language study, and fluency building (Nation, 2001). Both institutions have addressed these requirements for language development but with slightly different approaches and emphases.

Table 2 outlines writing lessons for a narrative paragraph or story to illustrate how language acquisition is supported through the four strands. It should be noted that the lessons vary somewhat in terms of activities from week to week. For example, although not included in the sample lessons in Table 2, the Institution 2 course incorporates discussion boards with written or video posts in some units. Institution 1 uses narrated and scripted PowerPoint presentations in addition to readings to provide input; in both cases, output opportunities may also include teacher technologically-mediated conferences. The peer tutor assignment at both institutions involves partnering the English language learner with a native English speaker for weekly appointments during the semester; however, Institution 2 has recently adapted this so that the second appointment is with a peer from the student's class. This is due to challenges finding a sufficient number of volunteer peer (student) tutors from the institution to serve in this role. Institution 1 has only one weekly peer tutor assignment. Deliberate language study activities are related to the writing pattern and topic in each lesson. Not included in the table are assessment elements. In both cases, these consist of various quizzes or exercises related to the instruction in each lesson. The table refers to the learning components in the lesson, which not only help students develop their capacity for autonomy, but further support linguistic development and build fluency. At Institution 1, this is a weekly assignment whereas at Institution 2, it occurs bi-weekly. A more detailed discussion of course components related to autonomy follows in the next section.

Table 2. Language Learning Components

\begin{tabular}{|c|c|c|}
\hline & Institution 1 & Institution 2 \\
\hline $\begin{array}{c}\text { Lesson } \\
\text { Outlines - } \\
\text { Narrative } \\
\text { Paragraph / } \\
\text { Story } \\
\text { Writing }\end{array}$ & $\begin{array}{l}\text { Input - reading and instructional } \\
\text { material about narrative } \\
\text { paragraph format and sentence } \\
\text { structure, including models of the } \\
\text { narrative pattern; } \\
\text { technologically-mediated tutor } \\
\text { appointment in which students } \\
\text { have the opportunity to listen to a } \\
\text { native English speaker } \\
\text { Output - first draft of paragraph } \\
\text { submitted for feedback; draft } \\
\text { shared with classmates in a } \\
\text { discussion board; classmates } \\
\text { respond to each other; } \\
\text { technologically-mediated } \\
\text { structured tutor appointment in }\end{array}$ & $\begin{array}{l}\text { Input - reading and instructional } \\
\text { materials about paragraph structure } \\
\text { and the writing process, including } \\
\text { models of the narrative pattern; } \\
\text { technologically-mediated tutor } \\
\text { appointment in which students have } \\
\text { the opportunity to listen to a native } \\
\text { English speaker } \\
\text { Output - write sentences to answer } \\
\text { questions about model stories; use a } \\
\text { chart to brainstorm ideas for story } \\
\text { topics; participate in a live class } \\
\text { session with other students living in } \\
\text { same geographical area to reinforce } \\
\text { lesson content; in the session, they } \\
\text { interview a classmate, write a }\end{array}$ \\
\hline
\end{tabular}




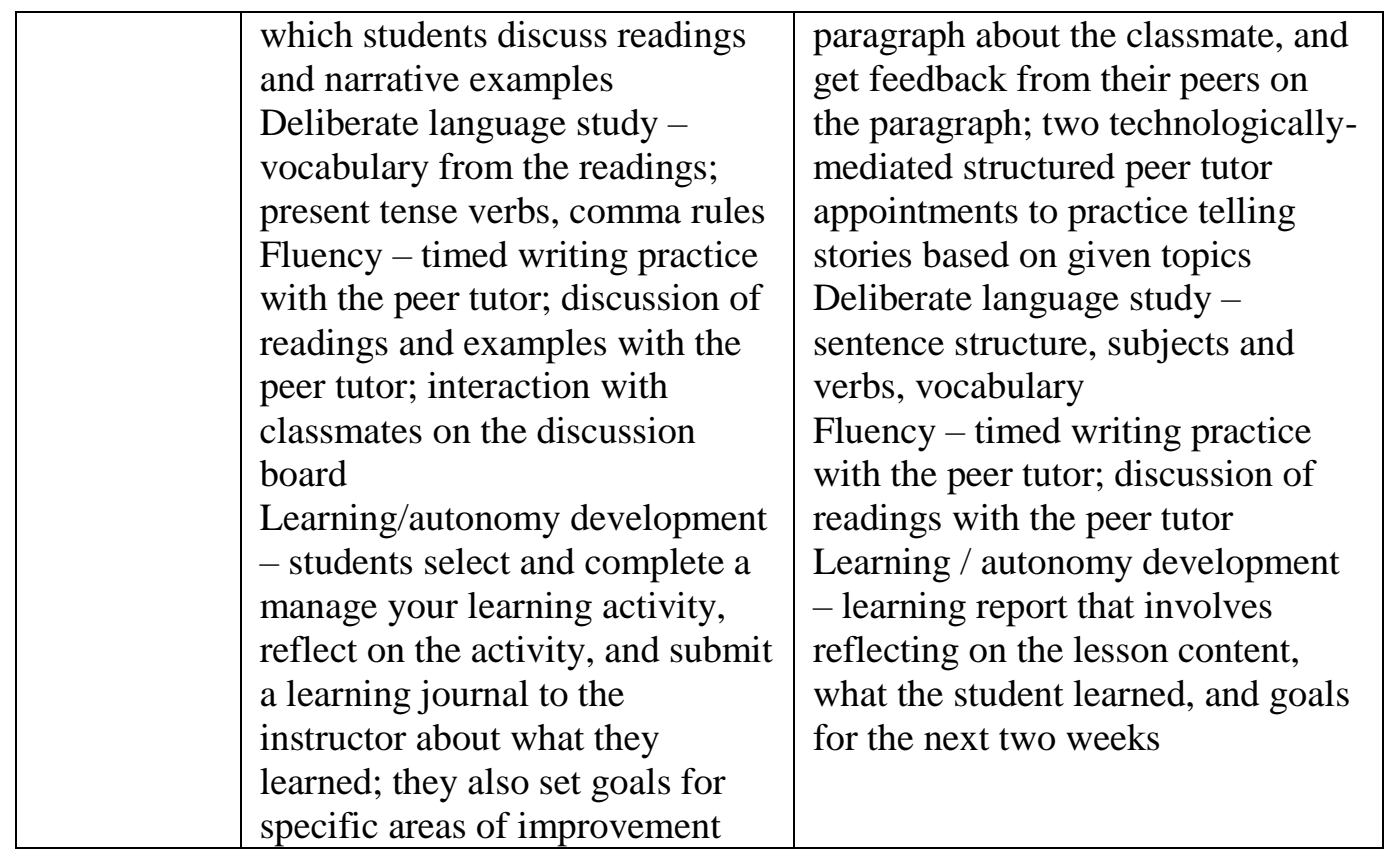

\section{Elements of Autonomy}

Autonomy involves the learner's ability to make appropriate decisions about what, when, where, and how to learn. Autonomy is characterized by selfdirection, self-awareness, active learning, goal setting, self-evaluation, taking responsibility or control, acting independently, and managing time (Garrison, 2003; Holec, 1981; Hurd, 1998, 2005; Little, 1991, White, 2003). These attributes are vital to successful distance learning. "Overall, the available research evidence suggests that promoting self-reflection, self-regulation and self-monitoring leads to more positive online learning outcomes. Features such as prompts for reflection, self-explanation and self-monitoring strategies have shown promise for improving online learning outcomes" (Means et al, 2010, p. 45).

In the courses at the two institutions of focus, elements of self-regulation and self-reflection are integrated into the course design. This is described in Table 3. 
Table 3. Learning Support Models

\begin{tabular}{|c|c|c|}
\hline & Institution 1 & Institution 2 \\
\hline $\begin{array}{l}\text { Autonomous } \\
\text { Learning } \\
\text { Development }\end{array}$ & $\begin{array}{l}\text { Students select an activity each } \\
\text { week related to motive for } \\
\text { learning, goal-setting, methods or } \\
\text { strategies for learning, time } \\
\text { management, help-seeking, their } \\
\text { study environment, or } \\
\text { performance / self-evaluation - } \\
\text { based on the dimensions of self- } \\
\text { regulated learning (Dembo et al, } \\
\text { 2006; Zimmerman, 1994). They } \\
\text { reflect on the activity through } \\
\text { guiding questions and submit } \\
\text { their reflection to the instructor } \\
\text { whose response facilitates more } \\
\text { in-depth analysis, revision of } \\
\text { goals, and further progress. } \\
\text { Learners submit a formal } \\
\text { performance evaluation at } \\
\text { midterm and the end of the } \\
\text { course. }\end{array}$ & $\begin{array}{l}\text { Learners engage in a three-stage } \\
\text { process in each unit. The first } \\
\text { stage is completing course } \\
\text { activities related to learning a } \\
\text { particular academic language } \\
\text { skill (e.g., a writing organization } \\
\text { pattern, grammar structure, etc.). } \\
\text { Following this practice, they } \\
\text { interact in discussion boards to } \\
\text { share their understanding of what } \\
\text { they have practiced, ask and } \\
\text { answer questions, and help each } \\
\text { other deepen their understanding. } \\
\text { This process is facilitated by the } \\
\text { instructor. The final stage } \\
\text { involves individual review, } \\
\text { reflection, and application. } \\
\text { Students respond to guiding } \\
\text { questions to complete a self- } \\
\text { assessment every other week in } \\
\text { which they reflect on their } \\
\text { learning and set goals. }\end{array}$ \\
\hline
\end{tabular}

Once again, although the various details of the courses differ, as do the activities and sequencing, in both cases, learners are guided incrementally through a structured learning process characterized by self-reflection and goal setting aimed at helping them develop greater responsibility for their learning. These activities also provide input and interaction opportunities, thereby integrating English language proficiency development with the development of autonomy.

\section{Outcomes}

The reflection journals and self-assessments in the courses provide overwhelming evidence of self-reported improvement and confidence with English, satisfaction with the learning approach, and praise for the overall experience. These outcomes are evident in the four student excerpts below.

1. I have enjoyed the program because it has been an enrichment experience. My motivation to learn helped me to conclude this program successfully; even though classes were hard, I could keep working in a full time job and also sharing time with my daughters and family. The program changed my perception about distance education. Since my first semester, I enjoyed the learning methods and available tools. 
2. As I progressed in each lesson, I found that my English was getting better and better. It was difficult when I started, but it got easier with each lesson. The introductory course was very interesting for me because it taught me how to set a goal, how to manage my time.

3. This program turns in my life so important and helpful, because I have improved my English, also grammar, and fluency, and now I do not get nervous when I talk with someone else in English. . . . I remember the first semester, it was so tedious, because my English was the worst, . . . but when I start to apply in my own life the learning model I started to improve in my English. Also something so helpful was my speaking partner. He helped me a lot to improve my comprehension and my accent. I gave my best during that semester and the award was an " $\mathrm{A}$ ".

4. I knew that by studying online I could have control of my time, but this was a new experience for me so I was nervous. I had not talked in English for a while, so I was also nervous about that. Despite this nervousness I felt that I had to be part of this experience, and time proved me right. . . . I am amazed how fast I recovered my fluency and how my vocabulary improved thanks to this class and having a speaking partner.

Although these are self-reported testimonials, other data such as test scores, advancement to higher level courses, and retention of self-regulated learning strategies are also evident (Andrade, in press; Andrade \& Bunker, 2011).

\section{Conclusions}

Innovative approaches are critical to meeting educational demand. They disrupt the status quo in higher education, which has survived for hundreds of years. The institutional approaches described are examples of disruptive innovations (Christensen \& Eyring, 2011); they make higher education accessible and affordable for large numbers of people rather than adhering to time-honored traditions of delivery, structure, and elitism. The approaches and specific course design models featured in this paper are focused on learner success so that opportunity can be expanded globally to enrich the lives of individuals, nations, and the worldwide community.

\section{References}

Allen, E., \& Seaman, J. (2014). Grade change: Tracking online education in the United States. Babson Park, MA: Babson Survey Research Group and Quahog 
Research Group. Retrieved from http://sloanconsortium.org/publications/survey/ grade-change-2013

Altbach, P, G., Reisberg, L., \& Rumbley, L. E. (2010). Trends in global higher education: Tracking an academic revolution. Paris: UNESCO. Retrieved from http://www.uis.unesco.org/Library/Documents/trends-global-higher-education2009-world-conference-en.pdf

Andrade, M. S. (in press). Dialogue and structure: Enabling learner self-regulation in technology enhanced learning environments. European Journal of Educational Research.

Andrade, M. S. (2014, April). International eLearning: Models for success. Proceedings of the $6^{\text {th }}$ International Conference on Computer Supported Education. Barcelona, Spain (pp. 7-14).

Andrade, M. S., Evans, N., \& Hartshorn, J. (2014). ESL students in higher education: Institutional approaches to a population at-risk. Journal of Student Affairs Research and Practice, 51(2), 207-221.

Andrade, M. S., Evans, N., \& Hartshorn, J. (in press). Perceptions and realities of ESL students in higher education: An overview of institutional practices. In Evans, N. W., Anderson, N. J., \& Eggington, W. G. (Eds.). ESL readers and writers in higher education: Understanding challenges, providing support.

Andrade, M. S. (2013). Global learning by distance: Principles and practicalities for learner support. International Journal of Online Pedagogy and Course Design, 3(1), 66-81.

Andrade, M. S. \& Bunker, E. L. (2011). Developing self-regulated distance language learners: A promising practice, in Proceedings of the Fourth Annual Selfregulated Learning in Technology Enhanced Learning Environments Barcelona, Spain: Targeted Cooperative Network of European Institutions (STELLARTACONET).

Arkoudis, S., Baik, C., \& Richardson, S. (2012). English language standards in higher education: From entry to exit. Camberwell, Australia: Australian Council for Educational Research.

Aud, S., Hussar, W., Kena, G., Bianco, K., Frohlich, L., Kemp, J., \&Tahan, K. (2011).The condition of education 2011 (NCES 2011-033). U.S. Department of Education, National Center for Education Statistics. Washington, DC: U.S. Government Printing Office. Retrieved from http://nces.ed.gov/pubsearch/pub sinfo.asp?pubid $=2011033$

Australian Universities Quality Agency (AUQA). (2009). Good practice principles forEnglish language proficiency for international students in Australian universities. Canberra; Department of Education, Employment and Workplace Relations. Retrieved from http://www.auqa.edu.au/files/otherpublications/good\% 20practice\%20principles\%20for\%20english\%20language\%20proficiency\%20re port.pdf

Birrell, B. (2006). Implications of low English standards among overseas students at Australian universities. People and Place, 14 (4), 53-64.

Carnevale, A. P., Smith, N., \&Strohl, J. (2010, June). Help wanted: Projections of jobs and education requirements through 2018. Washington, DC: The Georgetown University Center on Education and the Workforce. Retrieved from http://cew. georgetown.edu/jobs2018/

Choudaha, R., Chang, L., \& Kono, Y. (2013, March). International student mobility trends 2013: Towards responsive recruitment strategies. Retrieved from http:// www.wes.org/ewenr/13mar/feature.htm 
Christensen, C. \& Eyring, H. (2011). The innovative university: Changing the DNA of higher education from the inside out. San Francisco: Jossey-Bass.

Dembo, M. H., Junge, L.G., \& Lynch, R. (2006). Becoming a self-regulated learner: Implications for web-based education. In H. F. O’Neil, \& R. S. Perez (Eds.), Web-based learning: Theory, research, and practice (pp. 185-202). Mahwah, N. J: Lawrence Erlbaum Associates.

European Commission. (2014). Europe 2020. Retrieved from http://ec.europa. eu/europe2020/europe-2020-in-a-nutshell/targets/index_en.htm

Garrison, R. D. (2003). Self-directed learning and distance education. In M. G. Moore, \& W. G. Anderson (Eds.), Handbook of distance education (pp. 161-168). Mahwah, NJ: Lawrence Erlbaum.

Holec, H. (1981). Autonomy and foreign language learning: Council of Europe. Oxford: Pergamon Press.

Hurd, S. (1998). "Too carefully led or too carelessly left alone?" Language Learning Journal, 17, 70-74.

Hurd, S. (2005). Autonomy and the distance language learner. In B. Holmberg, M. Shelley, \& C. White (Eds.), Distance education and languages: Evolution and change (pp. 1-19). Clevedon, U.K: Multilingual Matters Ltd.

Institute of International Education. (2012). Open doors 2012 fast facts. Retrieved from http://www.iie.org/en/Research-and-Publications/Open-Doors

Krashen, S. (1985). The input hypothesis: Issues and implications. London: Longman.

Little, D. (1991). Learner autonomy 1: Definitions, issues, and problems. Dublin, Authentik.

Long, M. (1996). The role of the linguistic environment in second language acquisition. In W. Ritchie, \& T. Bhatia (Eds.), Handbook of second language acquisition (pp. 413-468). San Diego, CA: Academic Press.

Means, B., Toyama, Y., Murphy, R., Bakia, M., \& Jones, K. (2010, September). Evaluation of evidence-based practices in online learning: A meta-analysis and review of online learning studies. Washington, DC: U.S. Department of Education. Retrieved from http://www2.ed.gov/rschstat/eval/tech/evidence-ba sed-practices/finalreport.pdf

Nation, I. S. P. (2001). Learning vocabulary in another language. Cambridge University Press.

Swain, M. (1995). Three functions of output in second language learning. In G. Cook, \& B. Seidlhofer (Eds.), Principle and practice in applied linguistics (pp. 125144). Oxford University Press. Retrieved from http://www.scribd.com/doc/ 105840639/Swain-1995-Three-functions-of-output-in-second-language-learning

Utah Women and Education Initiative. (2014). Colleges \& universities. Retrieved from http://www.utahwomenandeducation.org/resources/resources-by-audience/ colleges-universities/.

White, C. (2003). Language learning in distance education. Cambridge: Cambridge University Press.

Zimmerman, B. J. (1994). Dimensions of academic self-regulation: A conceptual framework for education. In D. H. Schunk, \& B. J. Zimmerman (Eds.), Selfregulation of learning and performance (pp. 3-21). Hillsdale, N. J: Lawrence Erlbaum. 
